\title{
POTASSIUM DOES NOT ATTENUATE SALT STRESS IN YELLOW PASSION FRUIT UNDER IRRIGATION MANAGEMENT STRATEGIES ${ }^{1}$
}

\author{
GEOVANI SOARES DE LIMA ${ }^{2 *}$, JAILSON BATISTA DA SILVA ${ }^{2}$, FRANCISCO WESLEY ALVES PINHEIRO $^{3}$, \\ LAURIANE ALMEIDA DOS ANJOS SOARES ${ }^{2}$, HANS RAJ GHEYI ${ }^{3}$
}

\begin{abstract}
The objective of this study was to evaluate the gas exchange, growth and production of yellow passion fruit cv. BRS GA1, as a function of irrigation management strategies with saline water and potassium doses. The experiment was conducted under field conditions in São Domingos, PB, Brazil. A randomized block design was used in a $6 \times 2$ factorial scheme. The treatments consisted of six strategies of irrigation with saline waters (irrigation with low-salinity water throughout the crop cycle - SE; irrigation with high-salinity water in the vegetative stage - VE; flowering stage - FL; fruiting stage - FR; in the successive vegetative/flowering stages - VE/FL; vegetative/fruiting stages - VE/FR) and two doses of potassium (100 and $130 \%$ of the $\mathrm{K}_{2} \mathrm{O}$ recommendation), with four replicates and four plants per plot. The $100 \%$ dose corresponded to $60 \mathrm{~g}$ of $\mathrm{K}_{2} \mathrm{O}$ plant $^{-1}$ year ${ }^{-1}$. The effects of using high-salinity water $\left(3.2 \mathrm{dS} \mathrm{m} \mathrm{m}^{-1}\right)$ alternated with low-salinity water $\left(1.3 \mathrm{dS} \mathrm{m}^{-1}\right)$ were evaluated in different stages of the cultivation cycle. Irrigation with saline water in the fruiting stage promoted an increase in intercellular $\mathrm{CO}_{2}$ concentration and decrease in $\mathrm{CO}_{2}$ assimilation, with effects of non-stomatal origin standing out as limiting factors of photosynthetic efficiency. The highest $\mathrm{CO}_{2}$ assimilation rate in plants subjected to water salinity of $1.3 \mathrm{dS} \mathrm{m}^{-1}$ throughout the cycle resulted in increments in the number of fruits and in the production per plant of the passion fruit cv. BRS GA1.
\end{abstract}

Keywords: Passiflora edulis f. flavicarpa. Salt stress. Physiology. Yield.

\section{POTÁSSIO NÃO ATENUA O ESTRESSE SALINO NO MARACUJAZEIRO AMARELO SOB ESTRATÉGIAS DE MANEJO DE IRRIGAÇÃO}

RESUMO - Objetivou-se com este trabalho avaliar as trocas gasosas, o crescimento e a produção do maracujazeiro amarelo cv. BRS GA1, em função das estratégias de manejo de irrigação com águas salinas e doses de potássio. A pesquisa foi desenvolvida sob condições de campo em São Domingos, PB. Foi utilizado o delineamento de blocos casualizados em esquema fatorial $6 \times 2$, cujos tratamentos consistiram de seis estratégias de irrigação com águas salinas (irrigação com água de baixa salinidade durante todo ciclo de cultivo - SE; irrigação com água de alta salinidade na fase vegetativa - VE; de floração - FL; de frutificação - FR; nas fases sucessivas vegetativa/floração VE/FL; vegetativa/frutificação - VE/FR) e duas doses de potássio (100 e $130 \%$ de $\mathrm{K}_{2} \mathrm{O}$ da recomendação), com quatro repetições e quatro plantas por parcela. A dose de $100 \%$ correspondeu a $60 \mathrm{~g}$ de $\mathrm{K}_{2} \mathrm{O}$ planta $^{-1}$ ano $^{-1}$. Foram avaliados os efeitos do uso de água com alta salinidade $(3,2$ $\left.\mathrm{dS} \mathrm{\textrm {m } ^ { - 1 }}\right)$, em alternância com água de baixa concentração de sais $\left(1,3 \mathrm{dS} \mathrm{m}^{-1}\right)$, em fases diferentes do ciclo de cultivo. A irrigação com água salina na fase de frutificação promoveu incremento na concentração intercelular de $\mathrm{CO}_{2}$ e diminuição na assimilação de $\mathrm{CO}_{2}$, destacando-se os efeitos de origem não estomáticos como fatores limitantes da eficiência fotossintética. A maior taxa de assimilação de $\mathrm{CO}_{2}$ nas plantas submetidas à salinidade da água de $1,3 \mathrm{dS} \mathrm{m}^{-1}$ durante todo o ciclo, resultou em aumento no número de frutos e na produção por planta do maracujazeiro cv. BRS GA1.

Palavras-chave: Passiflora edulis f. flavicarpa. Estresse salino. Fisiologia. Produtividade.

\footnotetext{
${ }^{\text {"Corresponding author }}$

${ }^{1}$ Received for publication in 12/26/2019; accepted in 09/11/2020.

${ }^{2}$ Academic Unit of Agricultural Sciences, Center of Agrifood Science and Technology, Universidade Federal de Campina Grande, Pombal, PB, Brazil; geovani.soares@pq.cnpq.br - ORCID: 0000-0001-9960-1858, jailson.batista2015@hotmail.com - ORCID: 0000-0003-08394799, lauriane.soares@pq.cnpq.br - ORCID: 0000-0002-7689-9628.

${ }^{3}$ Academic Unit of Agricultural Engineering, Universidade Federal de Campina Grande, Campina Grande, PB, Brazil; wesley.ce@hotmail.com - ORCID: 0000-0002-5589-6882, hans@pq.cnpq.br - ORCID: 0000-0002-1066-0315.
} 


\section{INTRODUCTION}

Belonging to the Passifloraceae family, yellow passion fruit (Passiflora edulis f. flavicarpa) is a fruit crop widely cultivated in tropical and semitropical regions. Due to the physico-chemical quality and acceptance by consumers, its fruits are used for fresh consumption and agro-industrial processing in the preparation of carbonated and mixed beverages, syrups, jellies, dairy products, ice cream and canned foods (SANTOS et al., 2017). It has flowers with great ornamental potential, besides containing phytoconstituents in different parts of the plant that can be used for medicinal purposes (FALEIRO et al., 2019), due to the presence of polyunsaturated fatty acids and phenolic compounds with antioxidant activity (SANTOS et al., 2019).

In the 2018 season, the regions that stood out in terms of area planted with passion fruit crop were Northeast (29,593 ha), Southeast (5,708 ha), South $(3,648$ ha) and North (3,445 ha). Although the Northeast region has a larger planted area, it occupied the fourth position in terms of average yield, with $12,886 \mathrm{~kg} \mathrm{ha}^{-1}$. In this region, the states of Ceará, Piauí, Alagoas, Pernambuco and Bahia with average yields of 21,489, 14,462, 14,451, 11,869 and $10,275 \mathrm{~kg} \mathrm{ha}^{-1}$ stand out, respectively. The State of Paraíba recorded an average yield of $10,090 \mathrm{~kg} \mathrm{ha}^{-1}$, with an yield of $8,273 \mathrm{~kg} \mathrm{ha}^{-1}$ obtained in the Sertão Paraibano region (IBGE, 2018).

In the semi-arid region of Northeastern Brazil, due to the scarcity of water resources, the cultivation of passion fruit depends on irrigation. However, the available sources of water for irrigation generally have high concentrations of salts (DIAS et al., 2018). The excess of salts in the water causes reduction in the osmotic potential of the soil solution and compromises the main physiological processes of plants, such as gas exchange, water and ionic balance, including cell division, differentiation and expansion, and consequently plant growth and yield (BATISTA et al., 2019). In addition, salt stress also manifests as oxidative stress, due to the imbalance between the production of reactive oxygen species and their detoxification by enzymatic and non-enzymatic reactions, consequently leading to photooxidative damage to DNA, lipid membrane peroxidation, protein denaturation and, finally, cell death (MOHAMED et al., 2020).

Considering that, tolerance and sensitivity to salt stress vary according to plant species, cultivar, cationic and/or anionic nature, intensity and duration of stress, crop and irrigation management, edaphoclimatic conditions and plant development stages (SOARES et al., 2018). Thus, the use of high salinity water sources depends on strategies that ensure the sustainability of crops in the long term, particularly including the use of water sources with high salt concentration in stages of higher tolerance by the crop, mixture of waters of different qualities and cyclic conditions (LIMA et al., 2020b).

In order to enable the use of these resources in agriculture, potassium fertilization should also be considered as an alternative that can minimize salt stress in plants (ABBASI et al., 2016). Potassium stands out as attenuator of the deleterious effects of water salinity on crops (GURGEL; GHEYI; OLIVEIRA, 2010; PRAZERES et al., 2015; LIMA et al., 2018; DIAS et al., 2019). Potassium participates in protein synthesis, carbohydrate metabolism and as an enzymatic activator. It assists in cation-anion balance, osmoregulation, water movement, energy transfer and acts in reducing the generation of reactive oxygen species in plants (HASANUZZAMAN et al., 2018). $\mathrm{K}^{+}$promotes the efficient use of water by the plant and is a key element in the regulation of growth and development. Potassium application results in accumulation of osmolytes and increased antioxidant components in plants exposed to salt stress (AHANGER et al., 2017).

In this context, the objective of present study was to evaluate the gas exchange, growth and production of yellow passion fruit plants $\mathrm{cv}$. BRS GA1, as a function of irrigation management strategies with saline water and potassium doses.

\section{MATERIAL AND METHODS}

The experiment was carried out between November 2018 and July 2019, at the 'Rolando Enrique Rivas Castellón' experimental farm, belonging to the Center for Sciences and Agri-food Technology - CCTA of the Federal University of Campina Grande - UFCG, located in the municipality of São Domingos, Paraíba, PB, Brazil, at the coordinates: $6^{\circ} 48^{\prime} 50^{\prime \prime} \mathrm{S}$ latitude and $37^{\circ} 56^{\prime} 31^{\prime \prime}$ W longitude, at an altitude of $190 \mathrm{~m}$. It has an average annual rainfall of $700 \mathrm{~mm}$. According to Köppen's classification, adapted to Brazil (COELHO; SONCIN, 1982), the climate of the region is BSh (hot and dry). The temperature (maximum and minimum), relative humidity and rainfall data are shown in Figure 1.

The treatments were distributed in randomized blocks, in a $6 \times 2$ factorial scheme corresponding to irrigation strategies with saline waters (irrigation with low-salinity water throughout the crop cycle - SE; irrigation with high-salinity water in the vegetative stage - VE; flowering stage $\mathrm{FL}$; fruiting stage - FR; in the successive vegetative/ flowering stages -VE/FL; vegetative/fruiting stages VE/FR) and two doses of potassium (100 and 130\% of the $\mathrm{K}_{2} \mathrm{O}$ recommended by Costa et al. (2008) for passion fruit), with four replicates and four plants per plot. The dose of $100 \%$ corresponded to $60 \mathrm{~g}$ of $\mathrm{K}_{2} \mathrm{O}$ per plant ${ }^{-1}$ year $^{-1}$. 

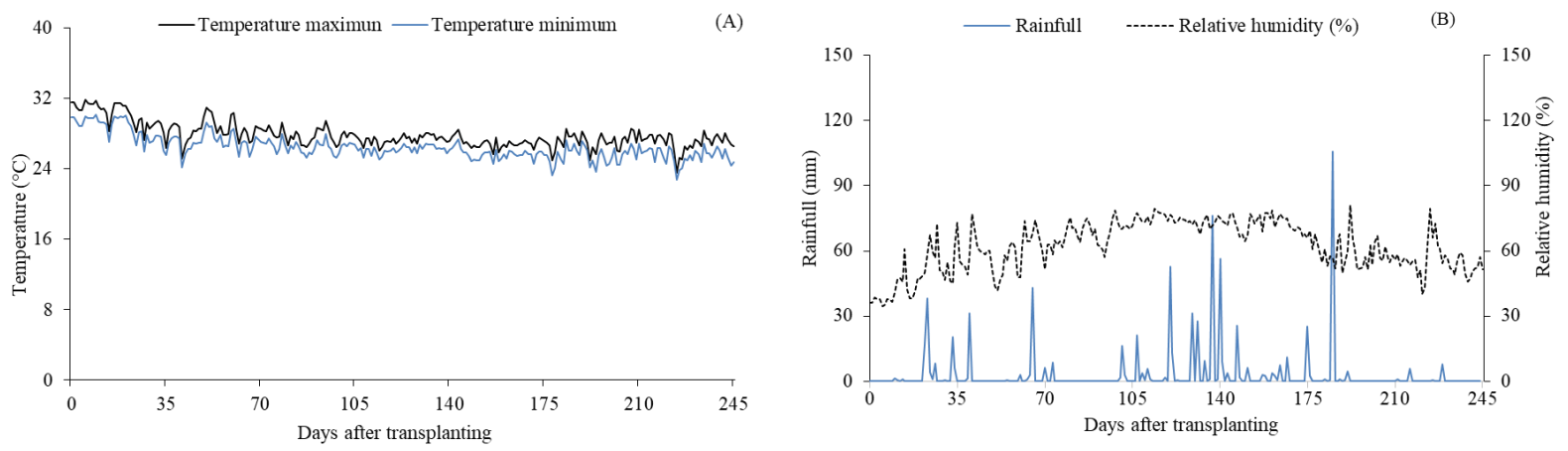

Figure 1. Data of average temperature (A), rainfall and relative humidity (B) during the experimental period.

The management strategies were established using two levels of salinity, expressed in terms of electrical conductivity of irrigation water $(\mathrm{ECw})$, one of low salinity $\left(1.3 \mathrm{dS} \mathrm{m^{-1 }}\right)$ and the other of high salinity $\left(3.2 \mathrm{dS} \mathrm{m}^{-1}\right)$, in the following stages of crop development: SE - irrigation with low-salinity water throughout the cultivation cycle (1-245 days after transplanting - DAT). Irrigation with high salinity water in VE - from transplanting until the emergence of the floral primordium (80-140 DAT); $\mathrm{FL}$ - from emergence of the floral primordium to full development of the floral bud (anthesis) (141-185 DAT); FR - from fertilization of the floral bud until the appearance of fruits with scattered yellow spots (186-245 DAT); VE/FL - irrigation with highsalinity water in the vegetative and flowering stages (80-185 DAT); and in VE/FR - in the vegetative and fruiting stages (80-140/186-245 DAT).

The seeds used came from the passion fruit cv. BRS GA1, which has fruits with oblong shape, slightly flattened base and apex, weighing from 120 to $350 \mathrm{~g}$, pulp yield around $40 \%$ and total soluble solids content ranging from 13 to $15^{\circ}$ Brix. It stands out for the homogeneity of the fruit, resistance to transport, bright yellow external color, pulp of strong yellow color (higher amount of vitamin C), longer shelf time and good pulp yield (EMBRAPA, 2008).

For seedling formation, two seeds were sown in plastic bags with dimensions of $15 \times 20 \mathrm{~cm}$, filled with substrate, consisting of $84 \%$ soil, $15 \%$ autoclaved sand and $1 \%$ aged bovine manure. After seedling emergence, thinning was performed, leaving only one plant per bag. During the seedling formation period, irrigation was performed using low-salinity water $\left(\mathrm{ECw}=1.3 \mathrm{dS} \mathrm{m}^{-1}\right)$. At 65 days after sowing (DAS), the seedlings were transplanted to the area in the field. Irrigation management with saline waters began at $80 \mathrm{DAT}$.

Tillage practices consisted of one plowing operation followed by harrowing, to break up clods and level the area. The soil of the experimental area was classified as Entisol with loamy sand texture. Before transplanting the seedlings to the field, soil samples were collected in the $0-40 \mathrm{~cm}$ layer and then mixed to form a composite sample, whose chemical and physical characteristics (Table 1) were determined according to the methodology proposed by Teixeira et al. (2017).

Table 1. Chemical and physical characteristics of the soil used in the experiment.

\begin{tabular}{|c|c|c|c|c|c|c|c|c|}
\hline \multicolumn{9}{|c|}{ Chemical characteristics } \\
\hline \multirow{2}{*}{$\begin{array}{c}\left.\mathrm{pH} \mathrm{H}_{2} \mathrm{O}\right) \\
(1: 2.5) \\
\end{array}$} & \multirow{2}{*}{$\begin{array}{c}\mathrm{OM} \\
\text { dag } \mathrm{kg}^{-1}\end{array}$} & \multirow{2}{*}{$\begin{array}{c}\mathrm{P} \\
\left(\mathrm{mg} \mathrm{kg}^{-1}\right)\end{array}$} & $\mathrm{K}^{+}$ & $\mathrm{Na}^{+}$ & $\mathrm{Ca}^{2+}$ & $\mathrm{Mg}^{2+}$ & $\mathrm{Al}^{3+}$ & $\mathrm{H}^{+}$ \\
\hline & & & \multicolumn{6}{|c|}{ 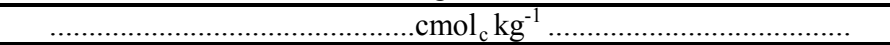 } \\
\hline 7.82 & 0.81 & 10.60 & 0.30 & 0.81 & 2.44 & 1.81 & 0.00 & 0.00 \\
\hline \multicolumn{9}{|c|}{ Chemical characteristics................. } \\
\hline \multirow{2}{*}{$\begin{array}{c}\mathrm{EC}_{\mathrm{se}} \\
\left(\mathrm{dS} \mathrm{m}^{-1}\right)\end{array}$} & \multirow{2}{*}{$\begin{array}{c}\text { CEC } \\
\mathrm{cmol}_{\mathrm{c}} \mathrm{kg}^{-1}\end{array}$} & \multirow{2}{*}{$\begin{array}{c}\text { SAR } \\
\left(\mathrm{mmol} \mathrm{L}^{-1}\right)^{0.5}\end{array}$} & \multirow{2}{*}{$\begin{array}{c}\text { ESP } \\
\%\end{array}$} & \multicolumn{3}{|c|}{ Size fraction $\left(\mathrm{g} \mathrm{kg}^{-1}\right)$} & \multicolumn{2}{|c|}{ Water content $\left(\right.$ dag kg $\left.{ }^{-1}\right)$} \\
\hline & & & & Sand & Silt & Clay & $33.42 \mathrm{kPa}^{1}$ & $1519.50 \mathrm{kPa}^{2}$ \\
\hline 1.52 & 5.36 & 6.67 & 15.11 & 820.90 & 170.10 & 9.00 & 12.87 & 5.29 \\
\hline
\end{tabular}

$\mathrm{pH}$-Hydrogen potential, OM -Organic matter: Walkley-Black Wet Digestion; $\mathrm{Ca}^{2+}$ and $\mathrm{Mg}^{2+}$ extracted with $1 \mathrm{M}$ $\mathrm{KCl}$ at $\mathrm{pH} 7.0 ; \mathrm{Na}^{+}$and $\mathrm{K}^{+}$extracted with $1 \mathrm{M} \mathrm{NH}_{4} \mathrm{OAc}$ at $\mathrm{pH} 7.0 ; \mathrm{Al}^{3+}+\mathrm{H}^{+}$extracted with $0.5 \mathrm{M} \mathrm{CaOAc}$ at $\mathrm{pH}$ 7.0; $\mathrm{EC}_{\mathrm{se}}$ - Electrical conductivity of the saturation extract; $\mathrm{CEC}$ - Cation exchange capacity; SAR -Sodium adsorption ratio of the saturation extract; ESP - Exchangeable sodium percentage; ${ }^{1}$ field capacity; ${ }^{2}$ permanent wilting point. 
The spacing used was $3 \mathrm{~m}$ between rows and $3 \mathrm{~m}$ between plants, using a trellis system with smooth wire $n^{\circ} 14$. A string was used to guide the plants to the trellis. When the plants reached $10 \mathrm{~cm}$ above the trellis, the apical bud was pruned to induce the growth of secondary branches, conducting one on each side up to the length of $1.10 \mathrm{~m}$. After the secondary branches reached this length, a new pruning of their apical buds was performed to stimulate the growth of tertiary branches, which were conducted up to $30 \mathrm{~cm}$ from the soil. During the experiment, tendrils and unwanted branches were eliminated in order to favor the development of the crop.

The dimensions of the pit holes for planting were $40 \times 40 \times 40 \mathrm{~cm}$. After opening the holes, fertilization was performed by applying $250 \mathrm{~g}$ of single superphosphate and $100 \mathrm{~g}$ of potassium chloride and, at the beginning of flowering, applying $150 \mathrm{~g}$ of single superphosphate $\left(18 \%\right.$ of $\mathrm{P}_{2} \mathrm{O}_{5}, 16 \%$ $\mathrm{Ca}^{2+}$ and $8 \% \mathrm{~S}$ ) per plant (SÃO JOSÉ, 2000). Nitrogen and potassium fertilizations were performed monthly, using urea $(45 \% \quad \mathrm{~N})$ and potassium chloride $\left(60 \% \mathrm{~K}_{2} \mathrm{O}\right)$ as sources of nitrogen and potassium, respectively. In the crop formation stage, a ratio of $1 \mathrm{~N}: 1 \mathrm{~K}$ was used based on the reference of $10 \mathrm{~g}$ of nitrogen; from the beginning of flowering, the $\mathrm{N}$ dose was increased to 20 and the $\mathrm{K}$ dose to $30 \mathrm{~g}$, hence increasing the $\mathrm{N}: \mathrm{K}$ ratio to $1: 1.5$ (SANTOS, 2001).

The irrigation water of the lowest level of electrical conductivity $\left(1.3 \mathrm{dS} \mathrm{m}^{-1}\right)$ came from an artesian well located in the experimental area of CCTA/UFCG, and the ECw level of $3.2 \mathrm{dS} \mathrm{m}^{-1}$ was prepared by the dissolution of $\mathrm{NaCl}$ in the well water (ECW of $1.3 \mathrm{dS} \mathrm{m}^{-1}$ ). The irrigation water with the highest level of salinity was prepared considering the relationship between $\mathrm{ECW}$ and salt concentration according to Richards (1954), as shown in Equation 1 :

$$
\mathrm{Q}\left(\mathrm{mmolc} \mathrm{L}^{-1}\right)=10 \times \mathrm{ECw}\left(\mathrm{dS} \mathrm{m}^{-1}\right)
$$

Where:

$\mathrm{Q}=$ Quantity of salts to be applied $\left(\mathrm{mmol}_{\mathrm{c}} \mathrm{L}^{-1}\right) ; \mathrm{ECw}=$ Electrical conductivity of water $\left(\mathrm{dS} \mathrm{m} \mathrm{m}^{-1}\right)$

Irrigation was applied using a localized drip system, with 32-mm-diameter PVC pipes in the main line and 16-mm-diameter, low-density polyethylene pipes in the lateral lines, using drippers with flow rate of $10 \mathrm{~L} \mathrm{~h}^{-1}$. In each plant, two pressurecompensating drippers (GA 10 Grapa model) were installed, each one at $15 \mathrm{~cm}$ distance from the stem. Plants were irrigated daily, at 7 a.m., with low or high salinity water, according to the adopted strategy, and the depth of irrigation was estimated based on crop evapotranspiration, according to (BERNARDO; SOARES; MANTOVANI, 2013), obtained by Equation 2:

$$
\mathrm{ETc}=\mathrm{ETo} \times \mathrm{Kc}
$$

Where: ETc - crop evapotranspiration, $\mathrm{mm}$ day $^{-1}$; ETo - reference evapotranspiration of Penman-Monteith, $\mathrm{mm} \mathrm{d}^{-1}$; and $\mathrm{Kc}$ - crop coefficient, dimensionless.

Reference evapotranspiration (ETo) was determined daily from climatic data collected at the São Gonçalo Weather Station, located in the municipality of Sousa - PB, and the data were used to determine ETo by the Penman-Monteith method. The crop coefficient corresponding to the phenological stage of the crop was used, according to the recommendation contained in Nunes (2016).

During the experiment, all the cultural practices and phytosanitary treatments recommended for the crop were carried out, monitoring the appearance of pests and diseases and adopting control measures when necessary.

At 200 days after transplanting (period of full flowering), gas exchange was evaluated using the following variables: stomatal conductance - $g s$ (mol of $\left.\mathrm{H}_{2} \mathrm{O} \mathrm{m} \mathrm{m}^{-2} \mathrm{~s}^{-1}\right)$, transpiration - $E$ (mmol of $\left.\mathrm{H}_{2} \mathrm{O} \mathrm{m}^{-2} \mathrm{~s}^{-1}\right), \mathrm{CO}_{2}$ assimilation rate $-A\left(\mu \mathrm{mol} \mathrm{m} \mathrm{m}^{-2} \mathrm{~s}^{-1}\right)$ and internal $\mathrm{CO}_{2}$ concentration - $C i\left(\mu \mathrm{mol} \mathrm{m} \mathrm{m}^{-2} \mathrm{~s}^{-1}\right)$. The diagnostic leaf to evaluate gas exchange was the third one, counted from the apex to the base of the fruit branch, using the portable photosynthesis meter "LCPro+" from ADC BioScientific Ltda, with irradiation source of $1200 \mu \mathrm{mol}$ photons $\mathrm{m}^{-2} \mathrm{~s}^{-1}$ and airflow of $200 \mathrm{~mL} \mathrm{~min}{ }^{-1}$, and $\mathrm{CO}_{2}$ from the environment at $3 \mathrm{~m}$ height from the soil surface.

Growth was evaluated at 80 and 245 DAT by determining stem diameter (SD) measured at $5 \mathrm{~cm}$ from the plant collar, using a digital caliper. These data were used to obtain the relative growth rates (RGRsd), adapting procedures contained in Benincasa (2003), according to Equation 3:

$$
\text { RGRsd }=\frac{(\operatorname{InSD} 2-\operatorname{InSD} 1)}{(\mathrm{t} 2--\mathrm{t} 1)}
$$

Where:

RGRsd = Relative growth rate of stem diameter $\left(\mathrm{mm} \mathrm{mm}^{-1}\right.$ day $\left.^{-1}\right), \mathrm{ln}=$ natural logarithm; $\mathrm{SD}_{1}=$ stem diameter $(\mathrm{mm})$ at time $\mathrm{t}_{1}, \mathrm{SD}_{2}=$ stem diameter $(\mathrm{mm})$ at time $\mathrm{t}_{2}$.

During the fruiting stage of the yellow passion fruit, which occurred between 150 and 245 DAT, the following parameters were determined: number of fruits (NF); total production (PRO), obtained by summing the weight of all fruits harvested per plant; and average fruit weight (AFW), determined by the ratio between the total fruit mass and the number of fruits per plant.

The data obtained were subjected to analysis of variance by the $\mathrm{F}$ test at 0.05 probability level. The means for $\mathrm{K}_{2} \mathrm{O}$ doses were compared by the $\mathrm{F}$ 
test $(\mathrm{p}<0.05)$, as is conclusive for two factors. Irrigation strategies with saline water were compared by the Tukey test at 0.05 probability. Statistical analysis was conducted using the statistical software Sisvar version 5.6 (FERREIRA, 2014).

\section{RESULTS AND DISCUSSION}

According to the summary of the analysis of variance water salinity management strategies significantly influenced stomatal conductance, transpiration, intercellular $\mathrm{CO}_{2}$ concentration and $\mathrm{CO}_{2}$ assimilation rate of the passion fruit cv. BRS
GA1 (Table 2). For potassium doses and the interaction between factors (MSW x PD), there was no significant difference on the passion fruit variables analyzed at 200 days after transplanting. Freire et al. (2014), conducting an experiment under field conditions in the municipality of Remígio, PB, to evaluate the gas exchange of yellow passion fruit cultivated under irrigation with water of low $\left(0.5 \mathrm{dS} \mathrm{m} \mathrm{m}^{-1}\right)$ and high $\left(4.5 \mathrm{dS} \mathrm{m} \mathrm{m}^{-1}\right)$ electrical conductivity, without and with bovine biofertilizer, without and with mulch, verified that water salinity significantly influenced only the stomatal conductance and $\mathrm{CO}_{2}$ assimilation rate.

Table 2. Summary of the analysis of variance for stomatal conductance $(g s)$, transpiration $(E)$, intercellular $\mathrm{CO}_{2}$ concentration $(\mathrm{Ci})$ and $\mathrm{CO}_{2}$ assimilation rate $(A)$ of the passion fruit cv. BRS GA1 cultivated under different irrigation management strategies with saline water and potassium doses, at 200 days after transplanting.

\begin{tabular}{cccccc}
\hline Source of variation & \multirow{2}{*}{ DF } & \multicolumn{4}{c}{ Mean squares } \\
\cline { 4 - 6 } & & $g s$ & $E$ & $C i$ & $A$ \\
\hline Management strategies with saline water (MSW) & 5 & $0.21^{* *}$ & $1.06^{*}$ & $18130.49^{* *}$ & $19.70^{* *}$ \\
Potassium doses (PD) & 1 & $0.003^{\text {ns }}$ & $0.37^{\text {ns }}$ & $173.65^{\text {ns }}$ & $1.35^{\text {ns }}$ \\
Interaction (MSW $\times$ PD) & 5 & $0.009^{\text {ns }}$ & $0.29^{\text {ns }}$ & $338.03^{\text {ns }}$ & $0.45^{\text {ns }}$ \\
Blocks & 2 & $0.004^{\text {ns }}$ & $0.05^{\text {ns }}$ & $205.44^{\text {ns }}$ & $0.95^{\text {ns }}$ \\
Residual & 22 & 0.020 & 0.21 & 689.17 & $0.65^{\text {ns }}$ \\
\hline CV (\%) & & 14.92 & 25.85 & 9.95 & 13.75 \\
\hline
\end{tabular}

$\mathrm{DF}=$ Degrees of freedom; $\mathrm{CV}=$ Coefficient of variation; ${ }^{\mathrm{ns},},{ }^{*},{ }^{* *}$ respectively not significant, significant at $\mathrm{p}<0.05$ and $\mathrm{p}<0.01$.

The stomatal conductance of the yellow passion fruit cv. BRS GA1 was negatively affected by the application of saline water (Figure 2A). It was verified that plants irrigated with low-salinity water throughout the cycle had higher values of $g_{s}$ compared to plants irrigated with saline water in the phenological stages VE, VE/FL, FL, FR and VE/FR, which in turn did not differ statistically. By comparing the gs of plants subjected to the VE, VE/ FL, FL, FR and VE/FR strategies with the $g s$ of those grown under the lowest salinity level (SE), the reductions observed were of $87.73,88.11,83.33$, 55.66 and $92.45 \%$, respectively. The lower values of stomatal conductance in plants irrigated with saline water occur due to the reductions in leaf turgor and atmospheric vapor pressure, which are ways to reduce the lag between the absorption of water by the roots and the transpiration, consequently leading to partial closure of the stomata as a strategy to avoid excessive dehydration of the guard cells (SUASSUNA et al., 2014), and can be attributed to stomatal and non-stomatal causes associated with the osmotic and toxic effects of excess salts (LÚCIO et al., 2013).

Lima et al. (2020a), when evaluating the gas exchange of 'BRS Rubi do Cerrado' passion fruit as a function of irrigation with saline waters $(\mathrm{ECW}$ ranging from 0.3 to $3.5 \mathrm{dS} \mathrm{m}^{-1}$ ), observed that $\mathrm{gs}$ decreased dramatically as the levels of irrigation water electrical conductivity increased. In another study, Silva et al. (2019) evaluated the gas exchange of 'Sugar Baby' watermelon plant, under irrigation strategies with saline waters (VE, VE/FL, FL, FR and MAT) and verified that the use of water with $\mathrm{ECw}$ of $3.2 \mathrm{dS} \mathrm{m}^{-1}$ during the vegetative/flowering and maturation stages inhibited stomatal conductance.

Regarding the transpiration of the passion fruit cv. BRS GA1 (Figure 2B), higher values were found in plants that received low-salinity water throughout the cycle (SE) and high-salinity water in the vegetative and flowering stages individually. However, there were no significant differences in plants irrigated with high-salinity water, regardless of the irrigation management strategy adopted. In relative terms, there were reductions of $31.51,37.94$, $30.03,34.59$ and $48.42 \%$ in the $E$ of plants subjected to VE, VE/FL, FL, FR and VE/FR strategies, respectively, in comparison to those that were irrigated with lower $\mathrm{ECW}$ level (SE). Under conditions of salt stress, the first response of the plant is to avoid the low water potential, adjusting its water balance between the absorption of water by the roots and the loss of water by the leaves. Stomatal closure and reduction of leaf area stand out as mechanisms to reduce water loss by leaf transpiration (CHEN et al., 2018). 


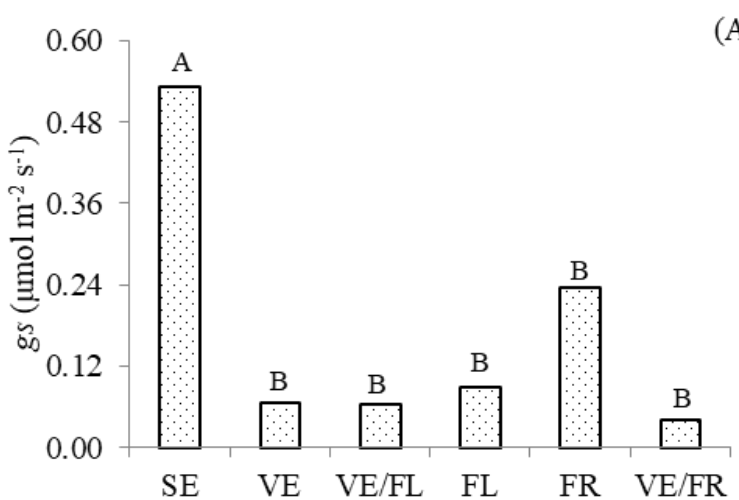

Management strategies with saline water

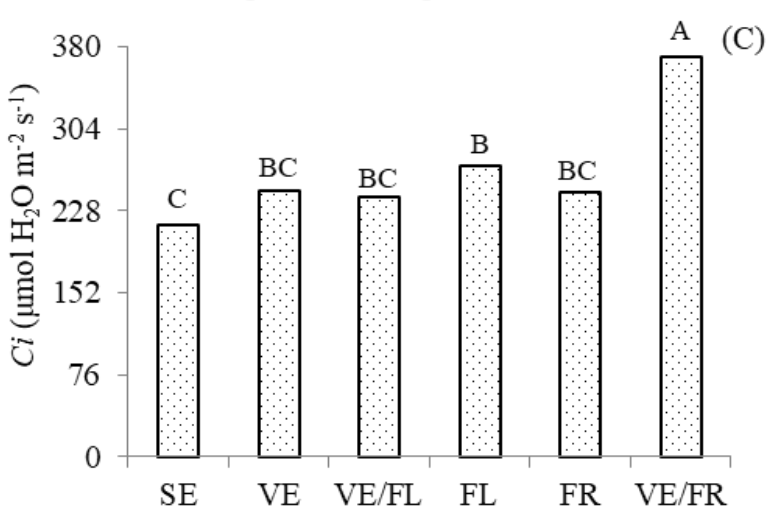

Management strategies with saline water
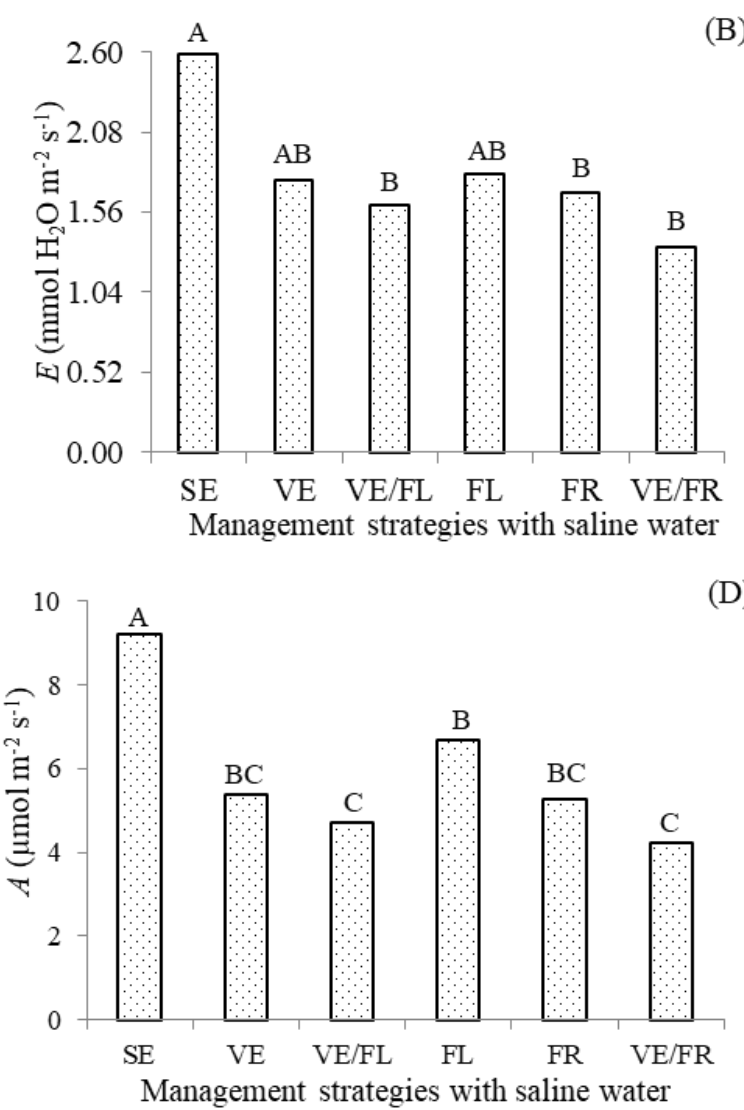

Means followed by different letters indicate a significant difference between treatments by Tukey test $(\mathrm{p}<0.05)$. SE irrigation with low-salinity water throughout the cultivation cycle (1-245 days after transplanting - DAT); VE - irrigation with high-salinity water in the vegetative stage (80-140 DAT); FL - flowering stage (141-185 DAT ); FR - fruiting stage (186-245 DAT); VE/FL - in successive vegetative/flowering stages (80-185 DAT); VE/FR - vegetative/fruiting stages (80140/186 -245 DAT).

Figure 2. Stomatal conductance $(g s)$, transpiration $(E)$, intercellular $\mathrm{CO}_{2}$ concentration $(C i)$ and $\mathrm{CO}_{2}$ assimilation rate $(A)$ of the passion fruit $\mathrm{cv}$. BRS GA1 as a function of irrigation management strategies with saline water, at 200 days after transplanting.

Under a condition of high evaporative demand, a typical situation in the semi-arid region of northeastern Brazil, the decrease in leaf transpiration stands out as a water saving strategy during the critical period, due to the reduction in the total water potential caused by the increase in salt concentration (SOUSA et al., 2014). In a study with passion fruit, variety 'Guinezinho', irrigated with saline waters ( $\mathrm{ECw}$ of 0.7 and $2.8 \mathrm{dS} \mathrm{m}^{-1}$ ) under greenhouse conditions, Andrade et al. (2019a) observed that the $\mathrm{ECw}$ reduced plant transpiration linearly, with decreases of 16.01 and $12.78 \%$ per unit increment in $\mathrm{ECw}$, at 61 and $96 \mathrm{DAT}$, respectively.

Unlike the stomatal conductance and leaf transpiration of passion fruit plants, the means comparison test (Figure 2C) showed that the water salinity applied continuously in the vegetative and fruiting stages resulted in increments of 42.10, 33.78, $35.04,27.44$ and $34.14 \%$ in the intercellular $\mathrm{CO}_{2}$ concentration, compared to plants that received the SE, VE, VE/FL, FL and FR strategies, respectively. By analyzing salinity management strategies, it was possible to observe that the lowest $C i(214.5 \mu \mathrm{mol}$ $\mathrm{H}_{2} \mathrm{O} \mathrm{m}^{-2} \mathrm{~s}^{-1}$ ) was obtained in plants irrigated with low-ECw water throughout the cycle, but there was no significant difference when compared to the treatments VE, VE/FL and FR. The reduction in intercellular $\mathrm{CO}_{2}$ concentration in plants subjected to low salinity throughout the cultivation cycle is consistent with the $\mathrm{CO}_{2}$ assimilation rate (Figure 2D). However, the increase in $\mathrm{Ci}$ observed in the VE/FR strategies is an indication that the $\mathrm{CO}_{2}$ fixed in leaf mesophyll cells was not used for the synthesis of sugars during photosynthesis, with its consequent accumulation (FREIRE et al., 2014), suggesting interference of some factor of non-stomatal origin in this process, which is confirmed through the values of $\mathrm{CO}_{2}$ assimilation (Figure 2D). 
In order to evaluate the gas exchange of yellow passion fruit irrigated with waters of low $(0.5$ $\left.\mathrm{dS} \mathrm{m}{ }^{-1}\right)$ and high $\left(4.5 \mathrm{dS} \mathrm{m}^{-1}\right)$ salinity, Freire et al. (2014) observed that the use of high-salinity water in irrigation led to an increase of $13.2 \%$ in $\mathrm{Ci}$, with values of $229.4 \mu \mathrm{mol} \mathrm{mol}{ }^{-1}$ in plants under $\mathrm{ECW}$ of

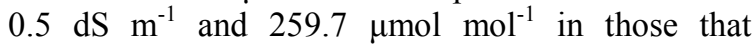
received the highest salinity level $\left(4.5 \mathrm{dS} \mathrm{m}^{-1}\right)$. In a study evaluating the gas exchange of genotypes of cotton (Gossypium hirsutum) under salt stress, during the stages of plant development, under conditions of low and high salinity, Soares et al. (2018) also found that there was an increase in the $C i$ of plants with the application of saline water in the different stages of development.

According to the means comparison test (Figure 2D), it was verified that plants subjected to the SE strategy obtained the higher $\mathrm{CO}_{2}$ assimilation rate $\left(9.8 \mu \mathrm{mol} \mathrm{H}_{2} \mathrm{O} \mathrm{m}^{-2} \mathrm{~s}^{-1}\right)$ in comparison to the other treatments tested (VE, VE/FL, FR, FL and VE/ FR). A comparison between the $\mathrm{CO}_{2}$ assimilation rate of passion fruit plants irrigated with water of lower $\mathrm{ECw}(\mathrm{SE})$ and the $\mathrm{CO}_{2}$ assimilation rate of those subjected to the VE, VE/FL, FL, FR and VE/ FR strategies showed reductions of $3.81,4.50,2.52$, 3.93 and $4.97 \mu \mathrm{mol} \mathrm{m} \mathrm{m}^{-2}$, respectively. However, there was no significant difference in the $A$ of plants subjected to high water salinity in the VE/FL, FR, and VE/FR stages and between the VE, FL and FR strategies. The decrease in $\mathrm{CO}_{2}$ assimilation rate in plants grown under high salinity is attributed not only to the closure of the stomata, but also to nonstomatal factors (ALAM et al., 2015).

According to the summary of the analysis of variance (Table 3), salinity management strategies interfered significantly only in the number of fruits and in the total production of yellow passion fruit. Potassium doses and the interaction between factors (MSW x PD) did not significantly influence the variables measured at 245 days after transplantation. Andrade et al. (2019b) also observed an effect similar to that of water salinity on the production of 'Guinezinho' passion fruit, recording a significant influence on the number of fruits and on the total production, at 205 days after transplanting.

Table 3. Summary of the analysis of variance for the relative growth rate in stem diameter (RGRsd) in the period of 80-245 days after transplantation (DAT) and for number of fruits (NF), total production (PRO) and average fruit weight (AFW) of the passion fruit $\mathrm{cv}$. BRS GA1 cultivated under irrigation management strategies with saline water and potassium doses, at 245 days after transplanting.

\begin{tabular}{|c|c|c|c|c|c|}
\hline \multirow{2}{*}{ Source of variation } & \multirow{2}{*}{ DF } & \multicolumn{4}{|c|}{ Mean squares } \\
\hline & & RGRsd & $\mathrm{NF}$ & $\mathrm{PRO}$ & AFW \\
\hline Management strategies with saline water (MSW) & 5 & $0.031^{\mathrm{ns}}$ & $20.05^{*}$ & $6.95^{*}$ & $0.03^{\mathrm{ns}}$ \\
\hline Potassium doses (PD) & 1 & $0.012^{\text {ns }}$ & $13.84^{\mathrm{ns}}$ & $1.84^{\mathrm{ns}}$ & $0.0009^{\mathrm{ns}}$ \\
\hline Interaction $(\mathrm{MSW} \times \mathrm{PD})$ & 5 & $0.024^{\mathrm{ns}}$ & $6.75^{\mathrm{ns}}$ & $0.13^{\mathrm{ns}}$ & $0.008^{\mathrm{ns}}$ \\
\hline Blocks & 2 & $0.032^{\text {ns }}$ & $3.36^{\mathrm{ns}}$ & $1.42^{\mathrm{ns}}$ & $0.013^{\mathrm{ns}}$ \\
\hline Residual & 22 & 0.019 & 4.72 & 0.91 & 0.021 \\
\hline $\mathrm{CV}(\%)$ & & 4.25 & 25.17 & 37.08 & 47.74 \\
\hline
\end{tabular}

$\mathrm{DF}=$ Degrees of freedom; $\mathrm{CV}=$ Coefficient of variation; ${ }^{\mathrm{ns}, ~}{ }^{*}$ respectively not significant and significant at $\mathrm{p}<0.05$.

The highest number of fruits in the passion fruit cv. BRS GA1 was obtained in plants irrigated with water without restrictions throughout the crop cycle (Figure 3A); however, it did not differ statistically from the treatments that were cultivated with high-salinity water $\left(3.2 \mathrm{dS} \mathrm{m}^{-1}\right)$ during the VE, $\mathrm{VE} / \mathrm{FL}$ and VE/FR stages. When using water with $\mathrm{ECw}$ of $3.2 \mathrm{dS} \mathrm{m}^{-1}$, there was a significant difference only between the VE/FL and FR strategies. In relative terms, it was observed that the NF of plants grown under $\mathrm{ECw}$ of $1.3 \mathrm{dS} \mathrm{m}^{-1}$ (SE) was 26.53, $7.67,35.71,43.28$ and $20.53 \%$ higher than those subjected to the VE, VE/FL, FL, FR and VE/FR strategies, respectively. The behavior of plants is affected by irrigation water salinity differently, depending on their stage of development. The relative reduction in the number of fruits in each stage of exposure reflects the negative effect of the osmotic potential of the soil solution on passion fruit plants cultivated, due to the inhibition of water and nutrient absorption and accumulation of potentially toxic ions $\left(\mathrm{Na}^{+}\right.$and $\left.\mathrm{Cl}^{-}\right)$in plant tissues (DIAS et al., 2011; ANDRADE et al., 2019b). In line with the results obtained in the present study, Dias et al. (2012) evaluated the effects of irrigation water salinity ( $\mathrm{ECW} 0.5$ to $4.5 \mathrm{dS} \mathrm{m}^{-1}$ ) on passion fruit production and also found reduction in the number of fruits, from 70 to $51.16(27 \%)$ fruits plant ${ }^{-1}$, between the ECw of 0.5 and $4.5 \mathrm{dS} \mathrm{m}^{-1}$. 

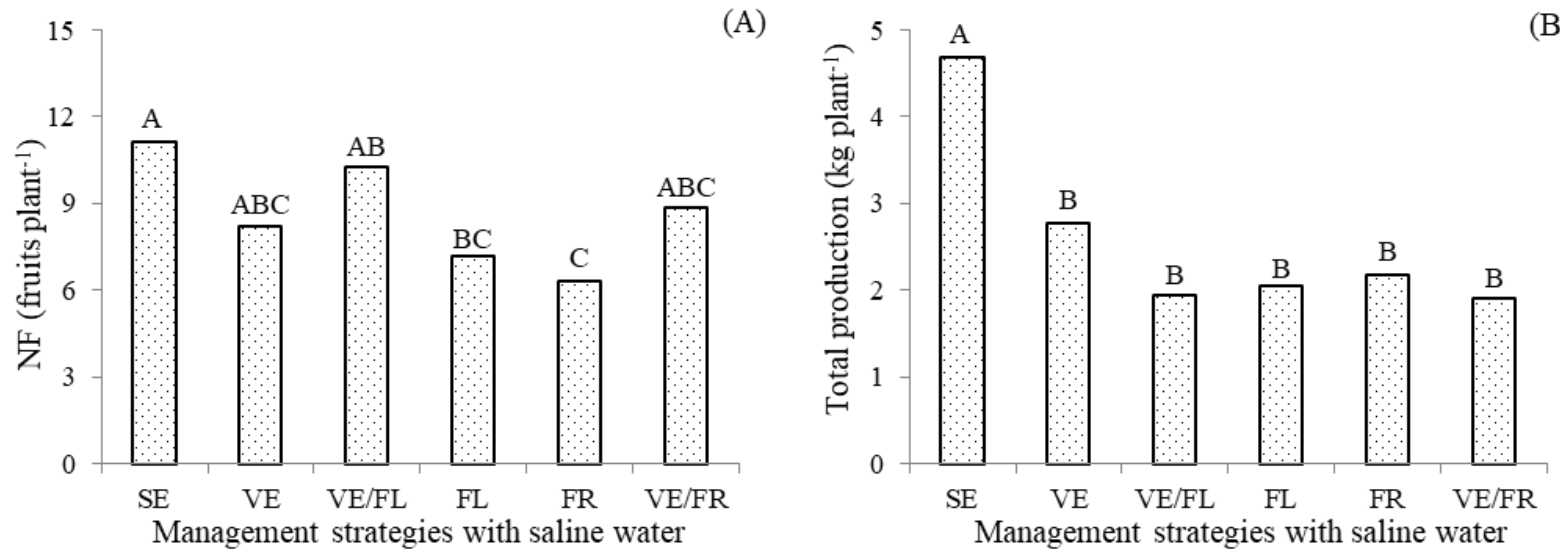

Means followed by different letters indicate a significant difference between treatments by Tukey test $(\mathrm{p}<0.05)$. SE irrigation with low-salinity water throughout the cultivation cycle (1-245 days after transplanting - DAT); VE - irrigation with high-salinity water in the vegetative stage (80-140 DAT); VE/FL in successive vegetative/flowering stages (80-185 DAT); VE/FR - vegetative/fruiting stages (80-140/186 -245 DAT).

Figure 3. Number of fruits - NF (A) and total production (B) of the passion fruit cv. BRS GA1 as a function of irrigation management strategies with saline water, at 245 days after transplanting.

The total production of the yellow passion fruit cv. BRS GA1 also differed significantly as a function of the use of water salinity management strategies, and its highest value $\left(4.68 \mathrm{~kg}\right.$ plant $\left.^{-1}\right)$ was obtained when low-salinity water was used in irrigation throughout the cultivation cycle (Figure 3B). On the other hand, plants irrigated under the strategies VE, VE/FL, FL, FR and VE/FR obtained production of $2.76,1.92,2.03,2.17$ and $1.90 \mathrm{~kg}$ plant $^{-1}$, respectively, that is, reductions of $1.92,2.76$, $2.65,2.51$ and $2.78 \mathrm{~kg} \mathrm{plant}^{-1}$, compared with that of the control treatment (SE). It is observed that the highest value in production is consistent with the results obtained for stomatal conductance (Figure 2A), transpiration (Figure 2B) and $\mathrm{CO}_{2}$ assimilation rate (Figure 2D) of the plants.

It should be noted that the energy expenditure for the maintenance of metabolic activities, that is, the maintenance of ionic and osmotic homeostasis, through the accumulation of sugars, organic acids and ions in the vacuole, stands out as a limiting factor in the production of crops under conditions of salt stress (SANTOS et al., 2012; LIMA et al., 2016). ANDRADE et al. (2019b) studied the influence of irrigation with saline water simulated with $\mathrm{NaCl}$ (ECW from 0.7 to $2.8 \mathrm{dS} \mathrm{m}^{-1}$ ) and observed higher production $\left(1.123 \mathrm{~kg}\right.$ plant $\left.^{-1}\right)$ in plants that received $\mathrm{ECW}$ of $0.7 \mathrm{dS} \mathrm{m}^{-1}$ and lower production $(0.216 \mathrm{~kg}$ plant $^{-1}$ ) in those subjected to $2.8 \mathrm{dS} \mathrm{m}^{-1}$, that is, a result lower than that obtained in the present study.

\section{CONCLUSIONS}

Irrigation with saline water in the fruiting stage promotes an increase in the intercellular $\mathrm{CO}_{2}$ concentration and decrease in $\mathrm{CO}_{2}$ assimilation, and the effects of non-stomatal origin stand out as limiting factors of the photosynthetic efficiency of yellow passion fruit plants cv. BRS GA1.

The higher $\mathrm{CO}_{2}$ assimilation rate in plants subjected to water salinity of $1.3 \mathrm{dS} \mathrm{m}^{-1}$ throughout the cultivation cycle promotes an increase in the number of fruits and in the production per plant of passion fruit.

Potassium doses of 100 and $130 \%$ of the recommendation do not significantly influence growth, gas exchange and production of passion fruit irrigated with saline water.

\section{ACKNOWLEDGMENTS}

To the National Council for Scientific and Technological Development (CNPq) for the financial assistance (Proc. CNPq 429732/2018-0) and research productivity grant (Proc. $\mathrm{CNPq}$ $309127 / 2018-1)$ to the first author.

\section{REFERENCES}

ABBASI, H. et al. Salt stress manifestation on plants, mechanism of salt tolerance and potassium role in alleviating it: a review. ZemdirbysteAgriculture, 103: 229-238, 2016.

AHANGER, M. A. et al. Plant growth under water/ salt stress: ROS production; antioxidants and significance of added potassium under such conditions. Physiology and Molecular Biology of Plants, 23, 731-744, 2017.

ALAM, A. et al. Effect of salinity on biomass yield and physiological and stem-root anatomical characteristics of purslane (Portulaca oleracea L.) 
accessions. BioMed Research International, 2015: $1-15,2015$.

ANDRADE, E. M. G. et al. Gas exchanges and growth of passion fruit under saline water irrigation and $\mathrm{H}_{2} \mathrm{O}_{2}$ application. Revista Brasileira de Engenharia Agrícola e Ambiental, 23: 945-951, 2019a.

ANDRADE, E. M. G. et al. Production and postharvest quality of yellow passion fruit cultivated with saline water and hydrogen peroxide. AIMS Agriculture and Food, 4: 907-920, 2019b.

BATISTA, V. C. V. et al. Salicylic acid modulates primary and volatile metabolites to alleviate salt stress-induced photosynthesis impairment on medicinal plant Egletes viscosa. Environmental and Experimental Botany, 167: 1-13, 2019.

BENINCASA, M. M. P. Análise de crescimento de plantas: noções básicas. 2.ed. Jaboticabal, SP: FUNEP, 2003. 42 p.

BERNARDO, S.; SOARES, A. A.; MANTOVANI, E. C. Manual de irrigação. 8 ed. Viçosa, MG: UFV. 2013. 625 p.

CHEN, D. et al. How does silicon mediate plant water uptake and loss under water deficiency? Frontiers in Plant Science, 9: e281, 2018.

COELHO, M. A.; SONCIN, N. B. Geografia do Brasil. São Paulo, SP: Moderna. 1982. 368 p.

COSTA, A. F. S. et al. Recomendações técnicas para o cultivo do maracujazeiro. Vitória, ES: Incaper, 2008. 56 p. (Incaper. Documentos, 162).

DIAS, A. S. et al. Gas exchanges and photochemical efficiency of West Indian cherry cultivated with saline water and potassium fertilization. Revista Brasileira de Engenharia Agrícola e Ambiental, 22: 628-633, 2018.

DIAS, A. S. et al. Gas exchanges, quantum yield and photosynthetic pigments of West Indian cherry under salt stress and potassium fertilization. Revista Caatinga, 32: 429-439, 2019.

DIAS, N. S. et al. Concentração salina e fases de exposição à salinidade do meloeiro cultivado em substrato de fibra de coco. Revista Brasileira de Fruticultura, 33: 915-921, 2011.

DIAS, T. J. et al. Qualidade física e produção do maracujá amarelo em solo com biofertilizante irrigado com águas salinas. Semina: Ciências Agrárias, 33: 2905-2918, 2012.
EMPRESA BRASILEIRA DE PESQUISA AGROPECUÁRIA - EMBRAPA. Híbrido de maracujazeiro azedo BRS Gigante Amarelo: Recomendações básicas de cultivo. 2 ed. Brasília, DF: EMBRAPA CERRADO, 2008. 2 p.

FALEIRO, F. G. et al. Advances in passion fruit (Passiflora spp.) propagation. Revista Brasileira de Fruticultura, 41: e-155, 2019.

FERREIRA, D. F. Sisvar: a guide for its bootstrap procedures in multiple comparisons. Ciência e Agrotecnologia, 38: 109-112, 2014.

FREIRE, J. L. O. et al. Rendimento quântico e trocas gasosas em maracujazeiro amarelo sob salinidade hídrica, biofertilização e cobertura morta. Revista Ciência Agronômica, 45: 82-91, 2014

GURGEL, M. T.; GHEYI, H. R.; OLIVEIRA, F. H. $\mathrm{T}$. Acúmulo de matéria seca e nutrientes em meloeiro produzido sob estresse salino e doses de potássio. Revista Ciência Agronômica, 41: 18-28, 2010 .

HASANUZZAMAN, M. et al. Potassium: a vital regulator of plant responses and tolerance to abiotic stresses. Agronomy, 8: 1-31, 2018.

INSTITUTO BRASILEIRO DE GEOGRAFIA E ESTATÍSTICA - IBGE, Produção agrícola: Lavoura permanente. 2018. Disponível em: $<$ https://cidades.ibge.gov.br/brasil/ pesquisa/15/11863>. Acesso em: 28 nov. 2019.

LIMA, G. S. et al. Emergence, growth, and flowering of castor beans as a function of the cationic composition of irrigation water. Semina: Ciências Agrárias, 37: 651-664, 2016.

LIMA, G. S. et al. Effects of saline water and potassium fertilization on photosynthetic pigments, growth and production of West Indian cherry. Revista Ambiente \& Água, 13: e2164, 2018.

LIMA, G. S. et al. Gas exchange, chloroplast pigments and growth of passion fruit cultivated with saline water and potassium fertilization. Revista Caatinga, 33: 184-194, 2020a.

LIMA, G. S. et al. Production characteristics of sesame genotypes under different strategies of saline water application. Revista Caatinga, 33: 490-499, 2020 b.

LÚCIO, W. S. et al. Crescimento e respostas fisiológicas do meloeiro inoculado com fungos micorrízicos arbusculares sob estresse salino. Semina: Ciências Agrárias, 34: 1587-1602, 2013. 
MOHAMED, I. A. A. et al. Stomatal and photosynthetic traits are associated with investigating sodium chloride tolerance of Brassica napus 1. cultivars. Plants-Basel, 9: 1-19, 2020.

NUNES, J. C. Trocas gasosas, composição mineral, produção e qualidade de maracujazeiro amarelo irrigado com água salina e adubado com potássio e biofertilizante. 2016. 164 p. (Doutorado em Agronomia: Área de Concentração em Agricultura Tropical). Universidade Federal da Paraíba, Areia, 2016.

PRAZERES, S. S. et al. Crescimento e trocas gasosas de plantas de feijão-caupi sob irrigação salina e doses de potássio. Revista Agro@mbiente, 9: 111-118, 2015 .

RICHARDS, L. A. Diagnosis and improvement of saline and alkali soils. Washington: U.S, Department of Agriculture, 1954. 160 p.

SANTOS, D. B. et al. Produção e parâmetros fisiológicos do amendoim em função do estresse salino. Idesia, 30: 69-74, 2012.

SANTOS, J. B. Estudo das relações nitrogênio: potássio e cálcio: magnésio sobre o desenvolvimento vegetativo e produtivo do maracujazeiro amarelo. 2001. 88 p. Dissertação (Mestrado em Manejo de Solo e Água: Área de concentração Solos e Nutrição de plantas). Universidade Federal da Paraíba, Areia, 2001.

SANTOS, O. V. et al. Efeitos do consumo de produtos e subprodutos do maracujá (Passiflora edulis) nas doenças crônicas não degenerativas. Brazilian Journal of health Review, 2:6226-6244, 2019.

SANTOS, V. A. et al. Produção e qualidade de frutos de maracujazeiro-amarelo provenientes do cultivo com mudas em diferentes idades. Revista de Ciências Agroveterinárias, 16: 33-40, 2017.

SÃO JOSÉ, A. R. Maracujá: Práticas de cultivo e comercialização. 1. ed. Vitória da Conquista, BA: UESB-DFZ, 2000. 316 p.

SILVA, S. S. et al. Gas exchanges and production of watermelon plant under salinity management and nitrogen fertilization. Pesquisa Agropecuária Tropical, 49: e54822, 2019.

SOARES, L. A. A. et al. Gas exchanges and production of colored cotton irrigated with saline water at different phenological stages. Revista Ciência Agronômica, 49: 239-248, 2018.
SOUSA, G. G. et al. Growth, gas exchange and yield of peanut in frequency of irrigation. Revista Ciência Agronômica, 45: 27-34, 2014.

SUASSUNA, J. F. et al. Trocas gasosas e componentes de crescimento em porta-enxertos de citros submetidos à restrição hídrica. Irriga, 19: 464$477,2014$.

TEIXEIRA, P. C. et al. Manual de métodos de análise de solo. 3. ed. Brasília, DF: Embrapa, 2017. $573 \mathrm{p}$. 